EL MUHASABA: Jurnal Akuntansi (e-Journal)

Volume 11, No. 2, Tahun 2020

P ISSN: 2086-1249 ; E ISSN: 2442-8922

\title{
PENGARUH RELIGIUSITAS DAN LOVE OF MONEY TERHADAP KEPATUHAN CALON WAJIB PAJAK
}

\author{
Eki Andhika Ratnawardhani ${ }^{1}$, Widi Dwi Ernawati ${ }^{2}$, Annisa Fatimah ${ }^{3}$ \\ Politeknik Negeri Malang \\ Jalan Soekarno Hatta 9, 6514 1,2,3 \\ e-mail: eki.andhika@polinema.ac.id
}

\begin{abstract}
The purpose of this study was to determine the effect of religiosity and Love of money on prospective taxpayer compliance. Population of this research was students at State Universities in Malang and the amount sample is 393 respondent that was obtained by using using purposive dan snowball sampling teqnique. The type of research is quantitative method using the associative causal method. Data coolestion is done by distributing questionnaries online and off line. The data analysis technique used in this study is multiple linear analysis. The results showed that the calculated value of t on the religiosity variable was 7,593, and the Love of money of 3,570 was greater than t table of 1,966. So religiosity and Love of money affect the compliance of prospective taxpayers. The variable that can explain the independent variable is $15.8 \%$, and the remaining $84.2 \%$ is influenced by other variables not explained in this study.
\end{abstract}

Keywords: Religiosity, Love of money, prospective taxpayer

\begin{abstract}
Abstrak
Tujuan penelitian ini adalah untuk menghetahui pengaruh religiusitas dan love of money terhadap kepatuhan calon wajib pajak. Populasi dalam penelitian ini adalah mahasiswa pada Perguruan Tinggi Negeri di kota Malang dan diperoleh sampel sebanyak 393 sampel melalui teknik purposive dan snowball sampling. Jenis Penelitian ini adalah kuantitatif menggunakan metode assosiative causal. Pengumpulan data dilakukan dengan menyebarkan kuesioner secara online dan offline kepada respoden. Teknik analisa data yang digunakan dalam penelitian ini adalah analisis linear berganda. Hasil penelitian menunjukkan nilai thitung pada variabel religiusitas sebesar 7,593, dan Love of money sebesar 3,570 lebih besar dari t tabel sebesar 1,966. Jadi religiusitas dan Love of money berpengaruh terhadap kepatuhan calon wajib pajak. Variabel yang dapat menjelaskan variabel independen sebesar 15,8\%, dan sementara sisanya 84,2\% dipengaruhi oleh variabel lain yang tidak dijelaskan dalam penelitian ini.
\end{abstract}

Kata Kunci: religiusitas, Love of money; kepatuhan wajib pajak

\section{PENDAHULUAN}

Tingkat rasio pajak Indonesia tergolong rendah $(10,7)$ jika dibanding dengan Malaysia $(14,3)$, Thailand $(16,5)$ dan negara Asia lainnya. Rasio pajak merupakan jumlah pajak yang dikumpulkan pada suatu masa berbanding dengan pendapatan nasional atau PDB di masa yang sama. Pendapatan negara yang berasal dari perpajakan sampai saat ini masih memberikan kontribusi terbesar bagi negara walaupun pendapatan dari sektor ini masih mengalami shortfall atau kurang dari target penerimaan. Shortfall penerimaan pajak disebabkan oleh rendahnya kepatuhan pajak (tax compliance) para wajib pajak.

Kepatuhan wajib pajak hingga kini menjadi masalah besar bagi otoritas pajak dan bukan tugas yang mudah meyakinkan wajib pajak untuk mematuhi peraturan perpajakan meskipun hukum pajak tidak selalu tepat (James and Alley 2004: 29). Kirchler (2008) mendefinisikan secara sederhana bahwa kepatuhan pajak adalah keinginan wajib pajak untuk membayar pajak mereka. Pada intinya kepatuhan pajak merupakan 
Eki Andhika Ratnawardhani, Widi Dwi Ernawati dan Annisa Fatimah : Pengaruh Religiusitas dan Love Of Money terhadap Kepatuhan Calon Wajib Pajak

kesadaran wajib pajak untuk mendaftarkan diri, menghitung serta melaporkan semua yang berkaitan dengan kewajiban perpajakan secara benar, jujur dan tepat waktu.

Secara umum kepatuhan wajib pajak dipengaruhi oleh dua faktor yakni faktor ekonomi dan faktor non ekonomi misalnya etika dan perilaku, faktor personal, sosial dan norma yang berlaku dalam masyarakat. Beberapa penelitian yang menguji faktor non eknomi antara lain adalah menggunakan konsep etika (Gosh \& Grain, 1996) dan moral (Kaplan, Newberry, \& Reckers, 1997). Penelitian ini menguji faktor non ekonomi yaitu religiusitas dan etika yang menggunakan Love of money sebagai variabel yang akan menjelaskan pengaruh terhadap tingkat kepatuhan wajib pajak.

Beberapa penelitian yang menggunakan religiusitas sebagai variabel yang mempengaruhi kepatuhan wajib pajak seperti Torgler (2003), Welch et al. (2005) dan Stack dan Kposowa (2006). Raihana, Mohdhali dan Pope (2012) menyatakan nilai-nilai agama yang diyakini oleh individu diharapkan mampu menciptakan sikap positif dan mencegah perilaku negatif dalam kehidupan sehari hari. Oleh karena itu religiusitas dianggap mampu memberikan motivasi positif serta keinginan yang kuat bagi pembayar pajak untuk mematuhi undang undang perpajakanan secara sukarela.

Pada konsep etika terdapat beberapa faktor yang mempengaruhi persepsi etis seseorang terhadap suatu tindakan pelanggaran. Salah satu faktor tersebut adalah uang. Tang menguji sebuah variabel psikologis baru yaitu individu cinta uang (Love of money). Penelitian Tang (1988) menghasilkan sebuah pengukuran yang disebut Money Ethic Scale (MES), yang termasuk di dalamnya adalah sikap positif, sikap negatif, pencapaian, kekuatan, pengelolaan uang, dan penghargaan. Melihat pentingnya uang dan perbedaan interpretasi atas uang, Tang (1992) menghasilkan konsep "the Love of money". Konsep tersebut digunakan untuk mengukur perasaan subjektif seseorang terhadap uang. Studi tersebut juga menunjukkan hubungan yang signifikan antara Love of money dan perilaku tidak etis. Borkowski dan Ugras (1998) menyatakan persepsi etis terkait dengan beberapa faktor yang unik setiap individu, dengan menguji variabel psikologis yang telah diterima dalam literatur psikologi yang merupakan kecintaan individu terhadap uang (Love of money). Kendra (2009) menyatakan secara psikologis, perilaku tidak etis memiliki hubungan yang tinggi dengan tingkat kecintaan terhadap uang atau persepsi individu terhadap uang. Individu yang memandang uang sebagai hal yang sangat penting bagi kehidupan mereka rentan terhadap kecurangan dan bertindak tidak etis. Penelitian ini mencoba menguji pengaruh Love of money terhadap tingkat kepatuhan sebagai representasi atas sikap etis yang dimiliki oleh individu.

Berdasarkan permasalahan diatas dan ditinjau dari beberapa penelitian terdahulu maka penelitian ini bertujuan untuk menguji kepatuhan calon wajib pajak yang dipengaruhi oleh religiusitas dan Love of money. Adapun rumusan masalah dalam penelitian ini adalah:

1. Apakah religiusitas memiliki pengaruh terhadap kepatuhan calon wajib pajak?

2. Apakah Love of money memiliki pengaruh terhadap kepatuhan calon wajib pajak?

Berdasarkan rumusan masalah yang telah dipaparkan sebelumnya, adapun tujuan dari penelitian ini adalah:

1. Untuk mengetahui pengaruh religiusitas terhadap kepatuhan calon wajib pajak

2. Untuk mengetahui pengaruh Love of money terhadap kepatuhan calon wajib pajak 
Eki Andhika Ratnawardhani, Widi Dwi Ernawati dan Annisa Fatimah : Pengaruh Religiusitas dan Love Of Money terhadap Kepatuhan Calon Wajib Pajak

Penelitian ini dilakukan secara empiris terhadap calon Wajib Pajak yaitu mahasiswa. Penelitian terdahulu belum menggali bagaimana sikap dan perilaku calon wajib pajak pada khususnya mahasiswa yang sebagai calon wajib pajak potemsial di masa yang akan datang. Mahasiswa yang digunakan dalam penelitian ini adalah mahasiswa yang telah memperoleh mata kuliah perpajakan, sehingga mereka sudah mendapatkan pengetahuan yang berkaitan dengan perpajakan.

\section{KAJIAN PUSTAKA}

Kepatuhan Wajib Pajak

Kepatuhan wajib pajak adalah tindakan seseorang melaporkan semua penghasilan kena pajak secara akurat, dan memperhitungkan semua penghasilan dalam menghitung pajak terutang dalam periode yang telah ditentukan tanpa harus menunggu tindak lanjut dari otoritas pajak (Singh, 2003). Definisi yang lebih luas atas kepatuhan pajak adalah tingkat kejujuran, pengetahuan yang memadai atas pajak dan kemampuan untuk menggunakan pengetahuan ini, ketepatan waktu, akurasi, dan catatan yang memadai dalam pengembalian pajak serta semua dokumentasi pajak terkait (Singh dan Bhupalan, 2001). Secara umum kepatuhan dapat diartikan sebagai motifasi seseorang kelompok atau organisasi untuk berbuat atau tidak berbuat sesuatu sesuai dengan aturan yang telah ditetapkan. Perilaku kepatuhan seseorang merupakan interaksi antara perilaku individu, kelompok dan organisasi. Dengan demikian kepatuhan dapat didefinisikan sebagai memasukkan dan melaporkan pada waktunya informasi yang diperlukan untuk mengisi secara benar jumlah pajak terutang dan membayar pajak pada waktunya tanpa ada tindakan pemaksaan.

Kriteria wajib pajak patuh menurut Keputusan Menteri Keuangan No.544/KMK.04/2000, wajib pajak patuh adalah sebagai berikut :

1. Tepat waktu dalam menyampaikan SPT untuk semua jenis pajak dalam dua tahun terakhir

2. Tidak mempunyai tunggakan pajak untuk semua jenis pajak, kecuali telah memperolah izin untuk mengatur atau menunda pembayaran pajak

3. Tidak pernah dijatuhi hukuman karena melakukan tindakan pidana di bidang perpajakan dalam jangka waktu lebih dari 10 tahun

4. Dalam dua tahun terakhir menyelenggarakan pembukuan dengan memadai dan dalam hal terhadap wajib pajak pernah dilakukan pemeriksaan, koreksi pada pemeriksaan yang terakhir untuk tiap-tiap jenis pajak yang terutang paling banyak $5 \%$

5. Wajib pajak yang laporan keuangannya untuk dua tahun terakhir diaudit oleh akuntan publik dangan pendapat wajar tanpa pegecualian atau pendapat dengan pengecualian sepanjang tidak memengaruhi laba rugi fiskal.

\section{Religiusitas}

Pancasila dalam sila pertama menunjukkan nilai Ketuhanan sebagai dasar negara hal itu dikarenakan Indonesia merupakan negara yang menjunjung tinggi Religiusitas. Johnson et al. (2001) mendefinisikan komitmen atau religiusitas religius sebagai "sejauh mana di mana seseorang berkomitmen pada agama dan ajarannya yang dianutnya, sedemikian rupa sehingga sikap dan perilaku individu mencerminkan komitmen ini. 
Eki Andhika Ratnawardhani, Widi Dwi Ernawati dan Annisa Fatimah : Pengaruh Religiusitas dan Love Of Money terhadap Kepatuhan Calon Wajib Pajak

Benk Serkan (2016) menyatakan Religiositas umumnya dilihat dalam penelitian sebelumnya menggunakan dua orientasi keagamaan, yaitu afiliasi keagamaan dan komitmen keagamaan. Afiliasi agama adalah asosiasi yang dikelompokkan berdasarkan agama, seperti menjadi seorang Muslim, Kristen, atau Buddha. Sedangkan, komitmen agama dibagi menjadi dua jenis, yaitu religiositas intrapersonal yang berasal dari kepercayaan dan sikap individu; dan religiusitas interpersonal yang berkembang dari keterlibatan individu dengan seorang religius komunitas atau organisasi.

Metode penanganan agama bekerja dua arah, secara positif dan negatif dengan stresor kehidupan; Namun, pola positif dari penanganan agama adalah lebih banyak digunakan oleh orang daripada pola negatif. Model akhir memandang agama sebagai prediktor perilaku, tetapi bukan sebagai variabel dependen atau independen. Ini karena banyak individu yang mengandalkan nilai-nilai agama sebagai sumber moralitas mereka untuk membentuk sikap dan perilaku mereka (Thornton \& Donald, 1989).

\section{Love of money}

Salah satu aspek yang sangat penting dalam kehidupan adalah uang. Di Amerika Serikat keberhasilan di ukur dengan uang dan pendapatan. Perilaku dan sikap terhadap uang pada manusia di peroleh melalui proses sosialisasi di mulai pada masa kanak-kanak hingga pada masa dewasa. Bahkan, didalam dunia bisnis perusahaan menggunakan uang untuk memotivasi, menarik serta mempertahankan karyawan (Milkovich dan Newman, 2002). Tang dalam penelitiannya memperkenalkan konsep "cinta uang" karena menganggap bahwa uang sangat penting dan memiliki interpretasi yang berbeda.

Dalam konsep tersebut, di ukur perasaan subjektif seseorang akan uang. Dari beberapa hasil penelitian di hasilkan bahwa Love of money terkait dengan beberapa perilaku organisasi misalnya tingkat kepuasan kerja yang tinggi, tingkat pergantian karyawan yang rendah dan perilaku organisasi yang tidak di inginkan seperti tidakan kecurangan akuntansi dan lain-lain.

Tang et al. (2000) menemukan bahwa kesehatan mental seorang profesional dengan tingkat Love of money terendah memiliki kepuasan kerja yang rendah. Tang dan Chiu (2003) berteori bahwa Love of money sangat terkait dengan konsep "ketamakan." Mereka menemukan bahwa karyawan Hong Kong dengan tingkat Love of money yang lebih tinggi kurang puas dengan pekerjaan mereka dibandingkan dengan rekan-rekan mereka". Chen dan Tang (2006) menyatakan bahwa hubungan tersebut dapat menyebabkan perilaku yang tidak etis. Bahkan, Tang dan Chiu (2003) juga menemukan hubungan yang langsung antara Love of money dan perilaku tidak etis di antara karyawan Hong Kong.

\section{HIPOTESIS}

Penelitian mengenai kepatuhan pajak secara umum menunjukkan hubungan yang positif antara religiusitas dengan kepatuhan pajak atau hubungan negatif antara religiusitas dan penggelapan pajak. Penelitian dari Stack dan Kposowa (2006, 349) memperkuat kesimpulan bahwa orang-orang tanpa afiliasi keagamaan lebih mungkin untuk melakukan penipuan pajak sebagai kegiatan yang dapat diterima. Penelitian yang dilakukan oleh Mohdali dan Paus (2012)menyelidiki dampak komitmen religiusitas 
Eki Andhika Ratnawardhani, Widi Dwi Ernawati dan Annisa Fatimah : Pengaruh Religiusitas dan Love Of Money terhadap Kepatuhan Calon Wajib Pajak

(intrapersonal dan religiusitas interpersonal) hanya pada salah satu dimensi dalam inventaris kepatuhan pajak, yaitu kepatuhan pajak sukarela yang mendasari niat perilaku wajib pajak. Penelitian lain telah dilakukan, namun belum ditemukan bukti yang mendukung religiusitas sebagai salah satu faktor yang mempengaruhi moral pajak (McKerchar et al. 2013, 18). McKerchar menemukan bahwa integritas pribadi dianggap memiliki efek yang lebih kuat pada sikap kepatuhan pajak mereka dibandingkan dengan keyakinan agama. Penelitian ini menguji religiusitas terhadap kepatuhan pajak

$\mathrm{H} 1$ : religiusitas berpengaruh terhadap kepatuhan calon wajib pajak

Penelitian telah dilakukan pengujian faktor-faktor non ekonomi terhadap tingkat kepatuhan wajib pajak. Akan tetapi penelitian tersebut belum menguji faktor Love of money sebagai variabel yang berpengaruh terhadap tingkat kepatuhan. Penelitian Tang dan Chiu (2003) menunjukkan bahwa karyawan Hongkong dengan Love of money lebih tinggi memiliki kepuasan kerja yang lebih kecil daripada teman kerjanya, sehingga terdapat kemungkinan melakukan tindakan yang tidak etis. Studi tersebut juga menunjukkan hubungan yang signifikan antara Love of money dan perilaku tidak etis dan memberi label Love of money merupakan akar dari kejahatan. Penelitian LunaArocas dan Tang (2004) memberikan hasil yang berbeda. Mereka berpendapat bahwa Love of money dapat membantu memprediksi dan mengendalikan perilaku tidak etis. Penelitian ini mencoba menguji pengaruh Love of money terhadap tingkat kepatuhan sebagai representasi atas sikap etis yang dimiliki oleh individu.

$\mathrm{H} 2$ : Love of money berpengaruh terhadap kepatuhan calon wajib pajak

\section{METODE}

Jenis penelitian adalah penelitian kausal komparatif, penelitian kausal komparatif (causal comparative research) merupakan tipe penelitian dengan karakteristik masalah berupa hubungan sebab akibat antara dua variabel atau lebih (Indriantoro dan Supomo, 2002:27).

Data yang digunakan dalam penelitian adalah data primer berupa kuesioner yang diisi oleh mahasiswa akuntansi Universitas Negeri Malang, Universitas Brawijaya, Universitas Islam Negeri Maulana Malik Ibrahim Malang dan Politeknik Negeri Malang yang telah menempuh mata kuliah Teori Perpajakan, Praktikum Perpajakan dan Manajemen Perpajakan.

Populasi penelitian ini mencakup seluruh mahasiswa akuntansi dari Perguruan Tinggi yang ditentukan. Populasi yang dapat diperoleh berdasarkan data adalah sebanyak 12.000 mahasiswa. Tidak semua Mahasiswa yang telah ditentukan digunakan sebagai sampel penelitian, sehingga untuk menentukan jumlah sampel dalam penelitian digunakan rumus Slovin yang berdasarkan perhitunganditentukan jumlah sampel yang dibutuhkan dalam penelitian ini adalah minimal sebanyak 388 responden.

Teknik pengambilan sampel adalah dengan purposive sampling dimana pengambilan sampel yang berdasarkan atas suatu pertimbangan tertentu seperti sifatsifat populasi ataupun ciri-ciri yang sudah diketahui sebelumnya.

Religiusitas dapat diartikan sebagai pemahaman, komitmen, dan tindakan agar berperilaku sesuai dengan aturan yang benar menurut keyakinannya pada kehidupan 
Eki Andhika Ratnawardhani, Widi Dwi Ernawati dan Annisa Fatimah : Pengaruh Religiusitas dan Love Of Money terhadap Kepatuhan Calon Wajib Pajak

individu. Variabel ini akan diukur menggunakan dimensi yang dikembangkan oleh Pope dan Mohdali (2010) meliputi interpersonal religiusitas dan intrapersonal religiusitas.

Love of money adalah perilaku seseorang terhadap uang, pengertian seseorang terhadap uang, serta keinginan dan aspirasi seseorang terhadap uang (Tang, Chen dan Sutarso, 2008). Love of money juga dapat diartikan sebagai tingkat kecintaan orang terhadap uang serta bagaimana seseorang menganggap pentingnya uang bagi mereka.

Dalam penetiliannya Tan mengembangkan Money Ethic Scale (MES) yang mengukur perasaan subjektif seseorang terhadap uang. Skala ini di gunakan untuk mengukur seberapa manusia cinta uang. Skala ini juga mengukur makna etis bagaimana seseorang menilai uang.

Meskipun ada beberapa skala uang lainnya, Mitchell dan Mickel (1999) menganggap MES merupakan survei yang paling baik dikembangkan untuk mengukur sikap terhadap uang. Pada kuesioner ini menggunakan enam faktor yang diidentifikasi sebagai berikut: good, evil,achievement, respect (self-esteem), budget, and freedom (power). Responden mencatat kesepakatan mereka atau ketidaksetujuan dengan skala lima poin, berkisar dari 1 (sangat tidak setuju) sampai 5 (sangat setuju).

Variabel terikat atau variabel dependen dalam penelitian ini adalah kepatuhan calon wajib pajak orang pribadi yang terkait dengan niatan-niatan yang akan dilakukan oleh calon wajib orang pribadi di masa depan atau di masa yang akan datang. Sehingga kepatuhan dapat didefinisikan sebagai memasukkan dan melaporkan pada waktunya informasi yang diperlukan untuk mengisi secara benar jumlah pajak terutang dan membayar pajak pada waktunya tanpa ada tindakan pemaksaan. Pengukuran variabel menggunakan empat indikator yang digunakan oleh Hamid (2017) serta dimodifikasi oleh peneliti untuk menyeseuaikan dengan variabel yang bersangkutan. Kepatuhan dapat diartikan sebagai motivasi seseorang kelompok atau organisasi untuk berbuat atau tidak berbuat sesuatu sesuai dengan aturan yang telah ditetapkan.

Dalam penelitian ini, hipotesis diuji dengan menggunakan regresi linier berganda untuk memperoleh gambaran menyeluruh mengenai pengaruh variabel independen terhadap variabel dependen. Persamaan regresi dalam penelitian ini adalah:

$Y=\alpha+\beta 1 X 1+\beta 2 X 2$

Keterangan :

$\mathrm{Y}=$ Kepatuhan calon wajib pajak

$a=$ Konstanta

$\beta \ldots=$ Koefisien regresi variabel independen

$\mathrm{X} 1$ = Religiusitas

$\mathrm{X} 2$ = Love of money

\section{HASIL DAN PEMBAHASAN}

Responden dalam penelitian ini adalah mahasiswa akuntansi Universitas Negeri Malang, Universitas Brawijaya, Universitas Islam Negeri Maulana Malik Ibrahim Malang dan Politeknik Negeri Malang yang telah menempuh mata kuliah Teori Perpajakan, Praktikum Perpajakan dan Manajemen Perpajakan. Pemilihan responden tersebut didasarkan pada pertimbangan bahwa nahasiswa yang dijadikan respon sudah memeliki 
Eki Andhika Ratnawardhani, Widi Dwi Ernawati dan Annisa Fatimah : Pengaruh Religiusitas dan Love Of Money terhadap Kepatuhan Calon Wajib Pajak

pengetahuan dan pemahaman terhadap hak dan kewajiban Wajib Pajak sesuai dengan peraturan pajak.

Sebelum melakukan pengujian hipotesis, dilakukan uji asumsi klasik untuk memastikan data berdistribusi normal, bebas multikolineritas, autokorelasi, dan heterokedastisitas dan penelitian ini memenuhi uji asumsi klasik.

Langkah berikutnya adalah melakukan analisis regresi berganda untuk menentukan besarnya pengaruh variabel independen Love of money terhadap variabel dependen yaitu kepatuhan calon wajib pajak dengan menggunakan model persamaanpersamaan berikut:

$$
\mathrm{Y}=\mathrm{a}+\mathrm{b} 1 \mathrm{X} 1+\mathrm{b} 2 \mathrm{X} 2
$$

Tabel 1. Hasil Uji Regresi

Coefficients

\begin{tabular}{|c|c|c|c|c|c|}
\hline \multirow[b]{2}{*}{ Model } & \multicolumn{2}{|c|}{$\begin{array}{c}\text { Unstandardized } \\
\text { Coefficients }\end{array}$} & \multirow{2}{*}{$\begin{array}{l}\text { Standardized } \\
\text { Coefficients } \\
\text { Beta }\end{array}$} & \multirow[b]{2}{*}{$\mathrm{t}$} & \multirow[b]{2}{*}{ Sig. } \\
\hline & B & Std. Error & & & \\
\hline (Constant) & 7.507 & 1.484 & & 5.057 & .000 \\
\hline X1 (Religiusitas) & .198 & .026 & .353 & 7.593 & .000 \\
\hline X2 (Love of money) & .079 & .022 & .166 & 3.570 & .000 \\
\hline
\end{tabular}

a. Dependent Variable: Y (Kepatuhan Calon Wajib Pajak)

\section{Sumber : Data Diolah}

Hasil analsisis regresi berganda dapat di buat persamaan regresi yaitu sebagai berikut:

$\mathrm{Y}=7.507+0,198 \mathrm{X} 1+0,079 \mathrm{X} 2$

Keterangan :

$\mathrm{Y}=$ Kepatuhan calon wajib pajak

$a=$ Konstanta

$\beta \ldots=$ Koefisien regresi variabel independen

$\mathrm{X} 1=$ Religiusitas

$\mathrm{X} 2$ = Love of money

Langkah pengujian berikutnya adalah menguji hipotesis apakah variabel independen berpengaruh terhadap variabel dependen digunakan uji koefisien determinasi, uji t (parsial) dan uji f (simultan). 
Eki Andhika Ratnawardhani, Widi Dwi Ernawati dan Annisa Fatimah : Pengaruh Religiusitas dan Love Of Money terhadap Kepatuhan Calon Wajib Pajak

a. $\quad$ Uji koefisien determinasi (R2)

Tabel 2. Hasil Uji Koefisien Determinasi

Model Summaryb

\begin{tabular}{|l|r|r|r|r|r|}
\hline Model & \multicolumn{1}{|c|}{$\mathrm{R}$} & R Square & \multicolumn{1}{c|}{$\begin{array}{c}\text { Adjusted R } \\
\text { Square }\end{array}$} & $\begin{array}{c}\text { Std. Error of the } \\
\text { Estimate }\end{array}$ & Durbin-Watson \\
\hline 1 & $.402^{\mathrm{a}}$ & .162 & .158 & 2.92666 & 1.893 \\
\hline
\end{tabular}

a. Predictors: (Constant), X2 (Love of money), X1 (Religiusitas)

b. Dependent Variable: Y (Kepatuhan Calon Wajib Pajak)

\section{Sumber : Data Diolah}

Hasil pengujian di atas, nilai koefisien determinasi (Adjusted $R$ Square) sebesar 0,158 . Artinya $15,8 \%$ variabel kepatuhan calon wajib pajak dipengaruhi oleh variabel religiusitas dan Love of money, sedangkan sisanya yaitu $100 \%-15,8 \%$ adalah $84,2 \%$ dipengaruhi oleh faktor lain yang tidak di bahas dalam penelitian ini.

b. Uji Parsial (uji t)

Tujuan dari uji parsial adalah untuk mengetahui seberapa jauh pengaruh dari variabel independen $(X)$ terhadap variabel dependen $(Y)$ secara parsial. Pengujian hipotesis akan dilakukan dengan menggunakan tingkat signifikansi sebesar 0,05 ( $\mathrm{a}=$ $5 \%$ ) atau tingkat keyakinan sebesar 95\%.

Dependent Variable: Y (Kepatuhan Calon Wajib Pajak)

Tabel 3. Hasil Uji Parsial (Uji t)

Coefficients $^{\mathrm{a}}$

\begin{tabular}{|c|c|c|c|c|c|}
\hline \multirow[b]{2}{*}{ Model } & \multicolumn{2}{|c|}{$\begin{array}{c}\text { Unstandardized } \\
\text { Coefficients }\end{array}$} & \multirow{2}{*}{$\begin{array}{l}\text { Standardized } \\
\text { Coefficients } \\
\text { Beta }\end{array}$} & \multirow[b]{2}{*}{$\mathrm{t}$} & \multirow[b]{2}{*}{ Sig. } \\
\hline & B & Std. Error & & & \\
\hline (Constant) & 7.507 & 1.484 & & 5.057 & .000 \\
\hline X1 (Religiusitas) & .198 & .026 & .353 & 7.593 & .000 \\
\hline X2 (Love of money) & .079 & .022 & .166 & 3.570 & .000 \\
\hline
\end{tabular}

a. Dependent Variable: Y (Kepatuhan Calon Wajib Pajak)

\section{Sumber : Data Diolah}

Berdasarkan perhitungan tabel dapat di ambil kesimpulan, yaitu:

a. Pengujian hipotesis pertama tentang Pengaruh Religiusitas terhadap Kepatuhan Calon Wajib Pajak, variabel religiusitas menunjukkan nilai signifikansi sebesar 0,000 dan nilai t hitung sebesar 7.593. Tingkat kesalahan 5\%, dan penetuan nilai $t$ tabel yaitu N - 2 atau 393 - 2 adalah 391. Nilai t tabel dengan jumlah sampel 391 adalah 
Eki Andhika Ratnawardhani, Widi Dwi Ernawati dan Annisa Fatimah : Pengaruh Religiusitas dan Love Of Money terhadap Kepatuhan Calon Wajib Pajak

sebesar 1,966. Variabel religiusitas memiliki nilai sig 0,000<0,05, dan nilai $\mathrm{t}$ hitung $>\mathrm{t}$ tabel atau 7.593 > 1,966 maka dapat disimpulkan bahwa Ho di tolak dan Ha diterima.

b. Pengujian hipotesis kedua tentang Love of money terhadap Kepatuhan Calon Wajib Pajak, variabel Love of money menunjukkan nilai signifikansi sebesar 0,000 dan nilai thitung sebesar 3.570. Tingkat kesalahan $5 \%$, dan penetuan nilai $\mathrm{t}$ tabel yaitu $\mathrm{N}$ 2 atau 393 - 2 adalah 391. Nilai t tabel dengan jumlah sampel 391 adalah sebesar 1,966. Nilai $\mathrm{t}$ tabel dengan jumlah sampel 391 adalah sebesar 1,966. Variabel Love of money memiliki nilai sig 0,000<0,05, dan nilai $\mathrm{t}$ hitung $>\mathrm{t}$ tabel atau $3.570>1,966$ maka dapat disimpulkan bahwa Ho di tolak dan Ha diterima.

c.Uji Simultan (Uji Statistik F)

Uji F menguji apakah semua variabel independen atau bebas yang dimasukkan dalam model mempunyai pengaruh secara bersama-sama terhadap variable dependen/terikat. Pada pengujian ini juga menggunakan tingkat signifikansi sebesar 5\% atau 0,05 .

Tabel 4. Hasil Uji Simultan (Uji F)

ANOVA $^{\mathrm{b}}$

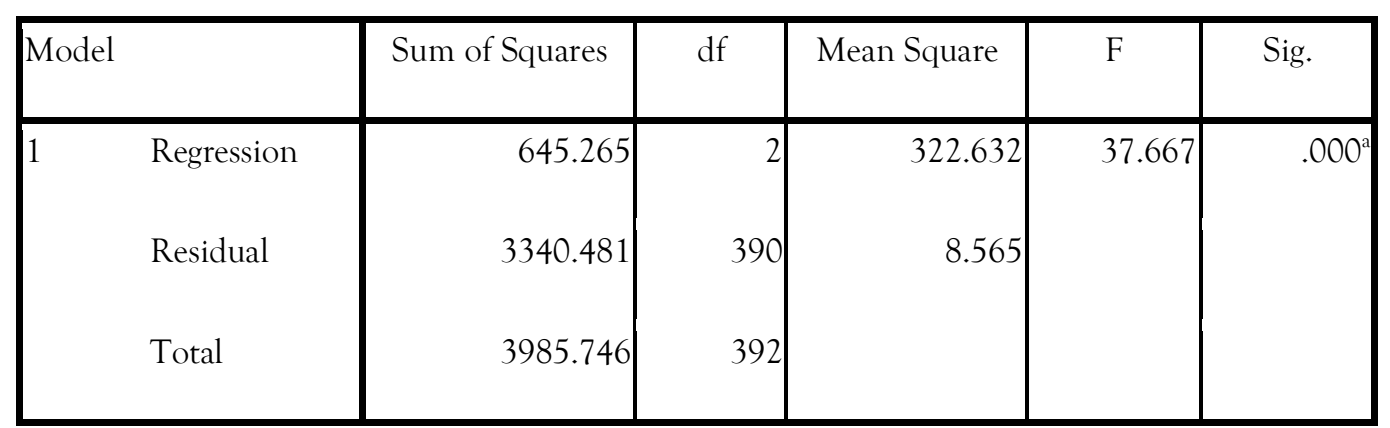

a. Predictors: (Constant), X2 (Love of money), X1 (Religiusitas)

b. Dependent Variable: Y (Kepatuhan Calon Wajib Pajak)

\section{Sumber : Data Diolah}

Tabel menunjukkan nilai $\mathrm{F}$ hitung sebesar 37.667 dengan nilai signifikansi sebesar 0,000, dengan tabel tersebutdapat diambil dua kesimpulan yaitu:

1. Dengan tingkat kesalahan sebesar $5 \%$, dan hasil signifikansi senilai $0,000<0,05$, maka Ho ditolak dan Ha diterima.

2. Nilai F hitung > F tabel atau $37.667>2,3949$ maka Ho ditolak dan Ha diterima.

Dari kesimpulan tersebut, berarti bahwa variabel religiusitas dan Love of money secara bersama-sama mempengaruhi kepatuhan calon wajib pajak. Hasil ini mendukung hasil penelitian Stack dan Kposowa $(2006,349)$ yang menyatakan bahwa orang-orang tanpa afiliasi keagamaan lebih mungkin untuk melakukan penipuan pajak sebagai kegiatan yang dapat diterima. Hal ini dapat dimaknai bahwa orang-orang yang mempunyai afiliasi keagamaan akan melakukan kepatuhan pajak sebagai kegiatan yang dapat diterima. Berdasarkan 12 item pertanyaan dalam kuesioner Religiositas yang berbunyi "Saya percaya bahwa setiap perbuatan manusia akan mendapatkan balasan dari Allah", item ini memperoleh jawaban tertinggi. Hal ini menunjukkan bahwa mahasiswa sebagai calon Wajib Pajak berkeyakinan jika berbuat tidak patuhmaka balasan dari Tuhan 
Eki Andhika Ratnawardhani, Widi Dwi Ernawati dan Annisa Fatimah : Pengaruh Religiusitas dan Love Of Money terhadap Kepatuhan Calon Wajib Pajak

pastilah berupa hal yang tercela pula. Jawaban tertinggi kedua adalah atas pertanyaan : "Agama sering menjadi dasar saya untuk menghadapi pilihan dalam kehidupan sehari-hari". Pada konteks ini, mahasiswa sebagai calon wajib pajak akan menggunakan agama sebagai landsan dalam memutuskan untuk patuh dan tidak patuh.

Tang et al. (2010) menyatakan bahwa sikap terhadap uang telah dipupuk sejak pada masa kanak-kanak dan dipelihara melalui kehidupan dewasa. Tang dan Chen (2008) berteori bahwa love of money sangat terkait dengan konsep "ketamakan". Selanjutnya Chen dan Tang (2006) menyatakan bahwa hubungan tersebut dapat menyebabkan perilaku yang tidak etis. Bahkan, Tang dan Chiu (2003) juga menemukan hubungan yang langsung antara love of money dan perilaku tidak etis di antara karyawan Hong Kong. Bahkan Ariely (2010) serta Gino dan Pierce (2009) menunjukkan adanya hubungan erat dengan uang. Sebagian besar orang menganggap bahwa love of money adalah akar dari semua kejahatan (Tang dan Chen, 2008). Hasil penelitian ini telah mengonfirmasi dan memberikan bukti tambahan untuk Tang et al. (2014) bahwa love of money memiliki dampak besar terhadap tindak kecurangan.

Ketika seseorang berpikir akan sangat menyenangkan untuk menjadi orang kaya dan menganggap uang menjadi hal yang paling penting dalam seluruh segi kehidupannya, maka secara tidak langsung memaksa mereka untuk berusaha lebih keras untuk mencari keuntungan termasuk dengan kecurangan pajak.

\section{KESIMPULAN}

Penelitian ini bertujuan untuk mengetahui pengaruh variabel religiusitas dan Love of money berpengaruh secara positif terhadap kepatuhan calon wajib pajak. Jumlah data yang dapat diolah adalah sebanyak 393 responden. Berdasarkan penelitian yang telah dilakukan diperoleh kesimpulan bahwa Religiusitas atau keyakinan terhadap agama seorang calon wajib pajak yang tinggi, memungkinkan calon wajib pajak menjalankan kewajiban perpajakan dengan baik dan dapat berkontribusi untuk meningkatkan kepatuhan calon wajib pajak di kemudian hari. Love of money atau kecintaan uang seorang calon wajib pajak tinggi, meskipun tidak banyak namun masih memiliki pengaruh untuk meningkatkan kepatuhan calon wajib pajak di masa depan.

\section{DAFTAR PUSTAKA}

Ariely, D. 2010. You are what you measure. Harvard Business Review, 88(6), 38.

Borkowski, S. C., \& Ugras, Y. J. (1998). Business students and ethics: A metaanalysis. Journal of Business Ethics, 17(11), 1117-1127.

Gino, F., \& Pierce, L. 2009. Dishonesty in the name of equity. Psychological Science.

James, S., dan Alley, C. 2000. Tax Compliance, Self-Assessment and Tax Administration. Journal of Finance and Management in Public Services, 2(2),27-42.

Kendra, C. (2009). Everything psychology book (2nd Edition): Retrieved from http://psychology.about.com/od/psychology101/u/psychology-theories.htm\#s1. 
Eki Andhika Ratnawardhani, Widi Dwi Ernawati dan Annisa Fatimah : Pengaruh Religiusitas dan Love Of Money terhadap Kepatuhan Calon Wajib Pajak

Kirchler, E., Hoelzl, E., dan Wahl, I. 2008. Enforced versus Voluntary Tax Compliance: The "Slippery Slope" Framework. Journal of Economic Psychology, 29(2), 210-225.

Mohdali, Raihana and Pope, Jeff. 2012. The effects of religiosity and external environment on voluntary tax compliance. New Zealand Journal of Taxation Law and Policy 18: pp. 119-139

Roth, J. A., Scholz, J. T., dan Witte, A. D. 1989. Taxpayer Compliance, Volume 1: An Agenda for Research. Philadelphia: University of Pennsylvania Press.

Stack, S., dan Kposowa, A .2006. The Effect of Religiosity on Tax Fraud Acceptability: A Cross-National Analysis. Journal for the Scientific Study of Religion, 45(3), 325-351.

Tang, T. L. P. (2010). Money, the meaning of money, management, spirituality, and religion. Journal of Management, Spirituality and Religion.

Tang, T. L. P. 2014. Theory of monetary intelligence: Money attitudes-religious values, making money, making ethical decisions, and making the grade. Journal of Business Ethics. doi:10.1007/s10551-014-2411-5.

Tang, T. L. P., \& Chen, Y. J. 2008. Intelligence vs. wisdom: The love of money, Machiavellianism, and unethical behavior across college major and gender. Journal of Business Ethics.

Tittle, C. R., dan Welch, M. R. 1983. Religiosity and Deviance: Toward a Contingency Theory of Constraining Effects. Social Forces, 61(3), 653-682.

Torgler, B. 2003. To Evade Taxes or Not to Evade: That is the Question. Journal of Socio-Economics, 32(3), 283-302.

Welch, M. R., Xu, Y., Bjarnason, T., Petee, T., O'Donnell, P., dan Magro, P. 2005. But Everybody Does It: The Effects Of Perceptions, Moral Pressures, And Informal Sanctions On Tax Cheating. Sociological Spectrum, 25(1), 21-52. 